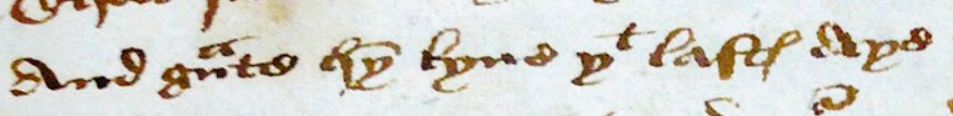

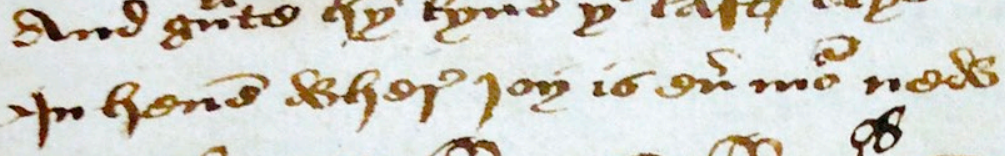

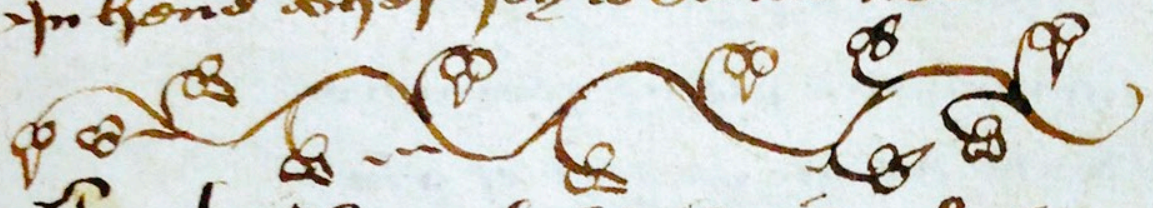

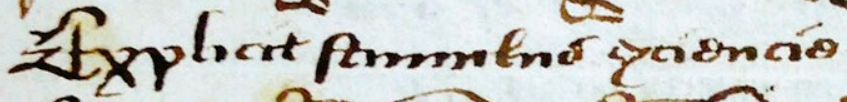

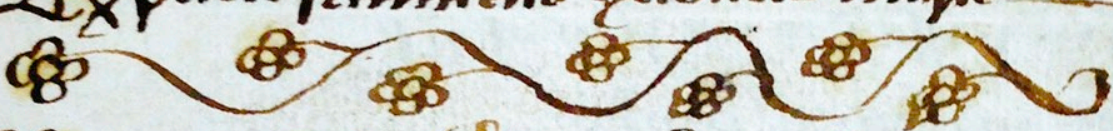

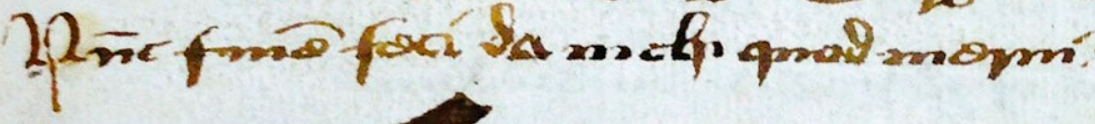

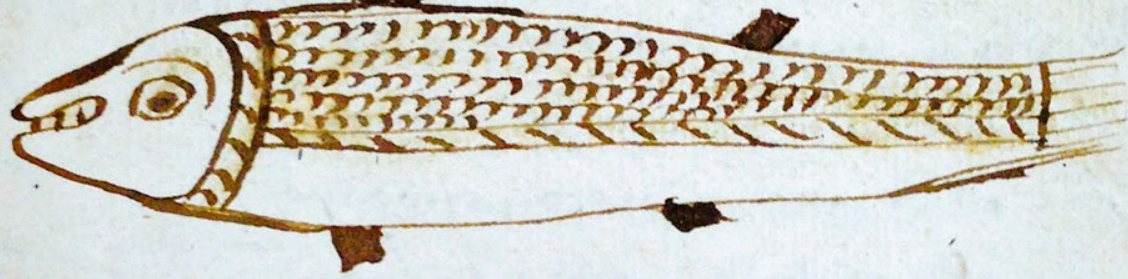
(33).

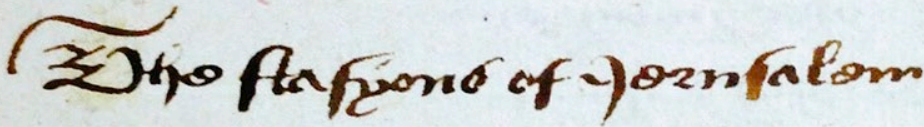

Objects of affection

The book and the household in late medieval England 


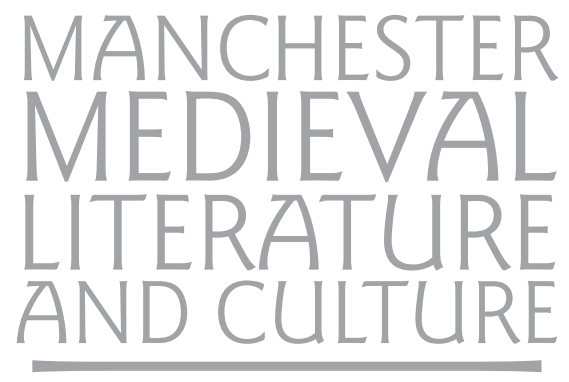

Objects of affection

\section{MANCHESTER 1824}

Manchester University Press 
Series editors: Anke Bernau, David Matthews and James Paz

Series founded by: J. J. Anderson and Gail Ashton

Advisory board: Ruth Evans, Patricia C.

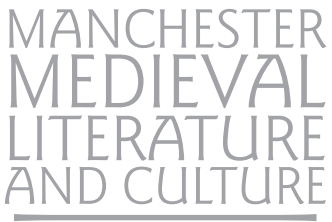
Ingham, Andrew James Johnston, Chris Jones, Catherine Karkov, Nicola McDonald, Haruko Momma, Susan Phillips, Sarah Salih, Larry Scanlon, Stephanie Trigg and Matthew Vernon

Manchester Medieval Literature and Culture publishes monographs and essay collections comprising new research informed by current critical methodologies on the literary cultures of the Middle Ages. We are interested in all periods, from the early Middle Ages through to the late, and we include post-medieval engagements with and representations of the medieval period (or 'medievalism'). 'Literature' is taken in a broad sense, to include the many different medieval genres: imaginative, historical, political, scientific, religious. While we welcome contributions on the diverse cultures of medieval Britain and are happy to receive submissions on Anglo-Norman, Anglo-Latin and Celtic writings, we are also open to work on the Middle Ages in Europe more widely, and beyond.

Titles available in the series

28. Household knowledges in late-medieval England and France Glenn D. Burger and Rory G. Critten (eds)

29. Practising shame: Female honour in later medieval England Mary C. Flannery

30. Dating Beowulf: Studies in intimacy Daniel C. Remein and Erica Weaver (eds)

31. Enacting the Bible in medieval and early modern drama Eva von Contzen and Chanita Goodblatt (eds)

32. Riddles at work in the early medieval tradition: Words, ideas, interactions Megan Cavell and Jennifer Neville (eds)

33. From Iceland to the Americas: Vinland and historical imagination Tim William Machan and Jón Karl Helgason (eds)

34. Northern memories and the English Middle Ages Tim William Machan

35. Harley manuscript geographies: Literary history and the medieval miscellany Daniel Birkholz

36. Play time: Gender, anti-Semitism and temporality in medieval biblical drama Daisy Black

37. Transfiguring medievalism: Poetry, attention and the mysteries of the body

Cary Howie 


\title{
Objects of affection
}

\section{The book and the household in late medieval England}

\author{
Myra Seaman
}

Manchester University Press 


\section{Copyright (C) Myra Seaman 2021}

The right of Myra Seaman to be identified as the author of this work has been asserted by her in accordance with the Copyright, Designs and Patents Act 1988.

Published by Manchester University Press

Altrincham Street, Manchester M1 7JA

www.manchesteruniversitypress.co.uk

British Library Cataloguing-in-Publication Data

A catalogue record for this book is available from the British Library

ISBN 9781526143815 hardback

First published 2021

The publisher has no responsibility for the persistence or accuracy of URLs for any external or third-party internet websites referred to in this book, and does not guarantee that any content on such websites is, or will remain, accurate or appropriate.

Front cover-

Bodleian Library MS Ashmole

61, fol. $127 \mathrm{v}-128 \mathrm{r}$.

Photo: () Bodleian Libraries, University of Oxford.

Typeset

by New Best-set Typesetters Ltd 